CASE REPORT

\title{
An unusual presentation of acquired hypothyroidism: the Van Wyk-Grumbach syndrome
}

\author{
E Baranowski and W Högler \\ Department of Endocrinology and Diabetes, Birmingham Children's Hospital, Steelhouse Lane, Birmingham B4 6NH, UK \\ (Correspondence should be addressed to E Baranowski; Email: ebaranowski@doctors.org.uk)
}

\begin{abstract}
The association in young females of long-standing primary hypothyroidism, isosexual precocious pseudopuberty and multicystic enlarged ovaries was first described in 1960 by Van Wyk and Grumbach. Since then, sporadic case reports have contributed to clarifying the key features of this syndrome. The unique elements that lead to this diagnosis are FSH-dominated sexual precocity combined with a delayed bone age in the presence of hypothyroidism. It is important to recognise this syndrome because initiating simple thyroid hormone replacement completely resolves symptoms and hormone abnormalities, avoiding unnecessary investigations for malignancies or surgical intervention. We describe an 8-year-old girl with autoimmune thyroiditis and severe long-standing hypothyroidism presenting with the clinical features of Van Wyk-Grumbach syndrome, a secondary TSH-secreting adenoma and hyperprolactinaemia. In addition, this girl presented with microcytic anaemia, elevated erythrocyte sedimentation rate (ESR) and two unusual features - a newly developed streaky hyperpigmented skin lesion and parathyroid hormone suppression despite vitamin D deficiency. Thyroxine replacement normalised all hormone abnormalities and shrunk the pituitary adenoma within 9 months, but the new skin lesion persisted. We review the literature and explore the pathophysiology of known and new features that give rise to speculation indicating stimulation of the FSH G protein-coupled receptor by excessive TSH, but LH suppression by hyperprolactinaemia.
\end{abstract}

European Journal of Endocrinology 166 537-542

\section{Introduction}

In 1960, Van Wyk and Grumbach first described a syndrome characterised by breast development, uterine bleeding and multicystic ovaries in the presence of longstanding primary hypothyroidism (1). On review of subsequent case reports, specific key elements of this disorder can be distinguished, characterising phenotype, imaging studies and biochemical changes (Table 1). Phenotypically, girls show the classical 'hypothyroid' appearance, delayed growth, folliclestimulating hormone (FSH)-mediated secondary sexual characteristics with breast development with or without galactorrhoea, uterine bleeding but absence of significant pubic or axillary hair development. Imaging studies typically reveal enlarged multicystic ovaries with follicular development, a pubertal uterus, enlarged pituitary gland, and unique to this cause of sexual precocity, delayed bone age. Biochemically, low free thyroxine $\left(\mathrm{T}_{4}\right)$ is combined with raised levels of thyroid stimulating hormone (TSH), prolactin and oestradiol. Typically, luteinising hormone-releasing hormone (LHRH) stimulation shows an FSH-dominated prepubertal response with suppressed luteinising hormone (LH), confirming gonadotropin-releasing hormone (GnRH)-independent precocious pseudopuberty $(2,3,4,5,6,7,8,9,10,11,12,13,14,15,16,17,18$, $19,20,21,22)$. Most cases in the literature are secondary to autoimmune thyroid disease but there are some case reports where the syndrome is secondary to unrecognised congenital hypothyroidism $(5,10,12)$. It is important to recognise this syndrome as symptoms regress with thyroid hormone replacement and patients spontaneously enter true puberty at an appropriate time $(2,3,4,5,6,7,8,9,10,11,12,13,14,15,16,17,18$, $19,20,21,22)$.

The majority of human hormones act through 7-transmembrane G protein-coupled receptors (GPCRs) of which many hundreds are described. They all share common intracellular signalling pathways but little is known about their distribution, activity and crossreactivity in hormone excess conditions (23).

We present a girl with both typical and unusual features of the Van Wyk-Grumbach syndrome, giving rise to speculation about hormonal overlap at the level of the GPCRs. 
Table 1 Summary of clinical findings in Van Wyk-Grumbach syndrome.

\begin{tabular}{lll}
\hline Phenotype & Imaging & Biochemistry \\
\hline Typical hypothyroid appearance & $\begin{array}{c}\text { Enlarged ovaries with multiple } \\
\text { follicular cysts } \\
\text { Pubertal uterus }\end{array}$ & $\begin{array}{c}\text { Extremely raised TSH and } \\
\text { low-undetectable free } \mathrm{T}_{4}\end{array}$ \\
$\begin{array}{ll}\text { Delayed growth } \\
\text { Precocious uterine bleeding }\end{array}$ & $\begin{array}{l}\text { Relayed bone age } \\
\text { High/high-normal FSH }\end{array}$ \\
$\begin{array}{l}\text { Precocious thelarche } \\
\pm \text { Galactorrhoea }\end{array}$ & Enlarged pituitary & Suppressed LH \\
Absence of pubic and axillary hair & & Flat response on LHRH stimulation test \\
& & Raised prolactin \\
\hline
\end{tabular}

\section{Case presentation}

A girl aged 8 years and 9 months was referred to the endocrinology department with a suspicion of precocious puberty after having had two episodes, 4 months apart, of per-vaginal bleeding lasting 3-4 days with associated cramp-like abdominal pain. She was of Pakistani origin, born at 37 weeks gestation with a birth weight of $2.36 \mathrm{~kg}$ and was of normal intelligence. Apart from mother's pre-eclampsia during pregnancy, there were no antenatal or postnatal difficulties. Routine neonatal blood spot screening was normal. She had no history of visual disturbance or headaches and had been generally well in herself. However, she had experienced some recent weight gain and poor growth, and had been prescribed iron supplements because of suspected iron deficiency anaemia. She had no family history of thyroid disease, autoimmunity or precocious puberty.

On examination, her height was $124.7 \mathrm{~cm}$ (9th-25th centile, mid-parental height target range 50th-98th centile), weight was $36.55 \mathrm{~kg}$ (91st centile) and she had breast development at Tanner's stage 2, but no pubic or axillary hair development. She also had a large, streaky hyperpigmented skin lesion in her left axilla and flank, which had newly developed over the previous months (Fig. 1).

Baseline LH was $0.2 \mathrm{U} / \mathrm{l}$, FSH $5.0 \mathrm{U} / \mathrm{l}$ and oestradiol was $<50 \mathrm{pmol} / \mathrm{l}$. Morning cortisol, 17-hydroxyprogesterone, androgens, human chorionic gonadotropin (hCG), $\alpha$-fetoprotein and IGF1 were normal. Primary hypothyroidism was demonstrated by a free $\mathrm{T}_{4}$ $<3.9 \mathrm{pmol} / \mathrm{l}$ with a TSH of $995 \mathrm{mU} / \mathrm{l}$. Positive thyroid peroxidase antibodies confirmed autoimmune thyroiditis; TPO antibody titre was $378 \mathrm{kU} / \mathrm{l}$ (normal range $0-35 \mathrm{kU} / \mathrm{l})$. Further blood tests highlighted a raised prolactin at $1310 \mathrm{mU} / \mathrm{l}$, deficient vitamin D $(16.2 \mathrm{nmol} / \mathrm{l})$ and a suppressed parathyroid hormone (PTH) of $7 \mathrm{ng} / \mathrm{l}(13-29)$, in the presence of normal calcium and phosphate. She had a raised white blood cell count of $14.9 \mathrm{gG} / \mathrm{l}$, raised ESR and severe, hyporegenerative, microcytic anaemia (Table 2). LHRH testing showed an FSH-dominated, prepubertal response with a 0-30 min FSH change from 6.7 to $6.5 \mathrm{U} / \mathrm{l}$ and an $\mathrm{LH}$ change from 0.1 to $0.4 \mathrm{U} / \mathrm{l}$. Her repeat oestradiol was raised $(164 \mathrm{pmol} / \mathrm{l})$.
A pelvic ultrasound scan found a pubertal uterus in size and appearance, and large, cystic ovaries with multiple dominant follicles (Fig. 2). A later pelvic magnetic resonance imaging (MRI) confirmed these findings. Contrasting with the pubertal development, her bone age was found to be delayed by 3 years. She went on to have an MRI of the brain, which showed a pituitary adenoma measuring $1.7 \times 1.7 \times 1 \mathrm{~cm}$ extending up to, but not compressing, the optic chiasm.

$\mathrm{T}_{4}$ treatment was started, purposely at a low dose of $25 \mu \mathrm{g}\left(22 \mathrm{mg} / \mathrm{m}^{2}\right)$ and increased gradually to 50,75 and then $100 \mu \mathrm{g}\left(88 \mathrm{mg} / \mathrm{m}^{2}\right)$ at her latest visit. Vitamin D deficiency was treated with 30000 units of

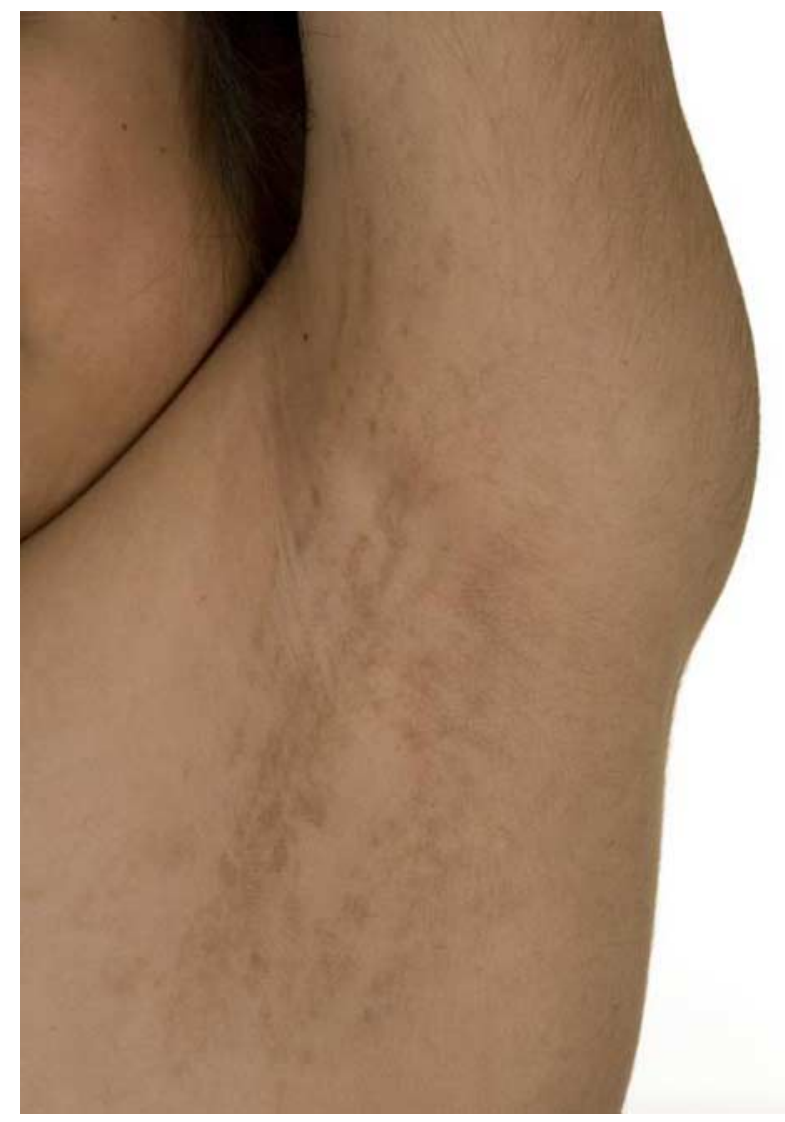

Figure 1 Newly developed streaky hyperpigmented lesion in the left axilla and chest wall. Full colour version of this figure available via http://dx.doi.org/10.1530/EJE-11-0494. 
Table 2 Blood test results.

\begin{tabular}{|c|c|c|c|}
\hline Test (normal range in brackets) & $\begin{array}{c}\text { Initial results } \\
\text { (age } 8 \text { y, } 9 \text { months) }\end{array}$ & $\begin{array}{l}\text { After } 3 \text { months } \\
\text { of treatment }\end{array}$ & $\begin{array}{l}\text { After } 9 \text { months } \\
\text { of treatment }\end{array}$ \\
\hline Free thyroxine $(10.7-21.8 \mathrm{pmol} / \mathrm{l})$ & $<3.9$ & 10.8 & 11.8 \\
\hline TSH $(0.40-3.50 \mathrm{mU} / \mathrm{l})$ & 955.0 & 7.90 & 20.7 \\
\hline TPO Ab titre $(0-35 \mathrm{kU} / \mathrm{l})$ & 378 & & \\
\hline Prolactin (mU/l) & 1310 & 218 & 198 \\
\hline $\mathrm{LH}(0.7-2.2 \mathrm{U} / \mathrm{l})$ & 0.2 & 0.5 & NA \\
\hline FSH $(0.2-6.0 \mathrm{U} / \mathrm{l})$ & 5.0 & 2.4 & 4.9 \\
\hline Oestradiol $(\mathrm{pmol} / \mathrm{l})$ & $<50$ & $<50$ & 54 \\
\hline Calcium $(2.20-2.60 \mathrm{mmol} / \mathrm{l})$ & 2.42 & & 2.33 \\
\hline Adjusted calcium $(2.20-2.60 \mathrm{mmol} / \mathrm{l})$ & 2.39 & & 2.33 \\
\hline Phosphate $(1.20-1.80 \mathrm{mmol} / \mathrm{l})$ & 1.19 & & 1.53 \\
\hline 25-Hydroxy vitamin D (>50 nmol/l) & 16.2 & & 40.5 \\
\hline Alkaline phosphatase (250-750 IU/I) & 510 & 1102 & 1051 \\
\hline PTH (13-29 ng/l) & 7 & 32 & 54 \\
\hline Calcitonin $(0.0-5.0 \mathrm{ng} / \mathrm{l})$ & 15.8 & & 4.2 \\
\hline ESR $(0-9 \mathrm{~mm} / \mathrm{h})$ & 50 & 18 & 28 \\
\hline Haemoglobin (12-14 g/l) & 8.4 & & 12.6 \\
\hline
\end{tabular}

TPO Ab, thyroid peroxidase antibody.

ergocalciferol/week and the anaemia with iron supplements. She had no further episodes of vaginal bleeding, and all her biochemistry returned to normal/expected values (Table 2). At her last review after 9 months of replacement therapy, her height was $134.1 \mathrm{~cm}(25 \mathrm{th}-50 \mathrm{th}$ centile) with a weight of $34.65 \mathrm{~kg}$ (75th centile), meaning that she had slimmed from a body mass index of 23.5 to $19.2 \mathrm{~kg} / \mathrm{m}^{2}$. The hyperpigmented lesion in the axilla/flank was unchanged. At this point her growth velocity had reached $14 \mathrm{~cm} /$ year, but she had now entered true puberty. A repeat brain MRI showed a massive reduction in pituitary size with a large sella and CSF-filled void as remnants of the previous TSH and prolactin hypersecretion.

\section{Discussion}

The pathophysiology of the Van Wyk-Grumbach syndrome involves a complex interaction between different hypothalamic-pituitary hormonal axes. In the original description, Van Wyk and Grumbach hypothesised that there was hormonal overlap in the pituitary feedback mechanism. This overlap was thought to be partly at the hormone molecular level, given that both TSH and gonadotropins are glycoproteins, and/or partly due to a lack of specificity at the hypothalamic level (1). TRH-induced TSH excess may be the common stimulator of the FSH receptor and possibly other GPCRs. The fascinating aspect of this syndrome is that TRH-induced hyperprolactinaemia likely suppresses the pituitary gonadotrophic axis, in particular LH, at the same time.

Stimulation of the gonadal FSH receptor by TSH is supported by the specific FSH/oestrogen dominant clinical picture and histopathologic findings. Girls with this syndrome have breast development, follicular cysts and menstruation in the absence of pubic or axillary hair, which depends on adrenal androgens $(2,3,4,5,6$, $7,8,9,10,11,12,13,14,15,16,17,18,19,20,21$, 22). Histopathological analysis of resected ovaries and ovarian cysts shows cystic follicles and little if any luteinisation. Some reports also noted myxoedematous infiltrates within affected ovaries, suggesting an independent role in cyst formation and abnormal steroidogenesis within the gonad $(1,2,3,4,5,6,18)$. Boys with this syndrome have macroorchidism without significant virilisation, and testicular histology shows a predominance of tubular elements without elevated Leydig cell number, consistent with an FSH-mediated response (24, $25)$. Thyroid hormone is known to affect testis growth and physiology, particularly during early development

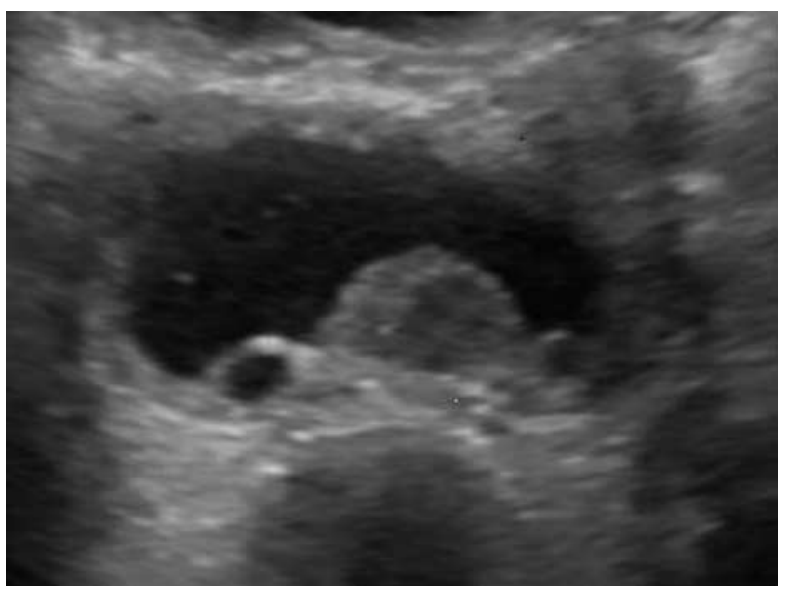

Figure 2 The ultrasound scan shows a pubertal uterus in size and appearance, measuring $5.3 \mathrm{~cm}$ in length, with a thickened endometrium $(1.2 \mathrm{~cm})$. Large, cystic ovaries with multiple dominant follicles were seen with one large thick-walled, irregular, complex cyst associated with the right ovary $(4 \times 1.5 \times 2.9 \mathrm{~cm})$, containing a smaller $1.3 \mathrm{~cm}$ diameter echogenic cyst within it. The right ovarian volume (including cyst) was $38.1 \mathrm{ml}$, and the left was $19.4 \mathrm{ml}$, with the largest follicle on the left measuring $1.4 \mathrm{~cm}$ in diameter. 
(26). The role of thyroid hormone receptors found on Sertoli and Leydig cells, in particular in this syndrome, is currently poorly understood. Because of the gonadal enlargement, and ovarian cyst formation, malignancy is often suspected, especially when accompanied by elevated ESR (7) and anaemia $(4,6,8,9,10)$, as in our case. Non-recognition can lead not only to a delay in diagnosis but also to unnecessary surgical procedures. Surgery should only be indicated if there is ovarian torsion or if the cystic enlargement does not regress with treatment $(4,6,9,11)$.

The peripubertal phase, where low FSH levels prevail, could be vulnerable to FSH receptor stimulation by TSH $(18,24,27)$ with cases very rarely being reported outside of this age group $(18,21,22)$. A dose-dependent response of the FSH receptor to TSH is assumed as only very few children, all with extremely high TSH levels, are affected. This hypothesis is well supported by in vitro experiments $(24,27)$. The glycoproteins TSH, FSH, LH and hCG share a common $\alpha$-subunit but have a unique $\beta$-subunit that is specific to each hormone. They each act through transmembrane GPCRs to activate adenylate cyclase and stimulate cAMP production (23). Anasti et al. (24) showed that recombinant human TSH elicited a dose-dependent response at the human FSH receptor. The TSH concentration required was several orders of magnitude higher than FSH, demonstrating that the FSH-like activity of TSH is very low. They went on to show that TSH and FSH are acting through the same receptor and that TSH competitively antagonises FSH. This response was not generic for all glycoproteins as adenylate cyclase activity in transfected cells was unresponsive to hCG. The concept of overlap between the glycoprotein hormones in times of hormone excess is not unprecedented - for example, hCG is used to stimulate LH receptors as a test of testicular function in boys due to the homology of their $\beta$-subunits (28).

To test whether a mutation or allelic variation in affected individuals leaves them more susceptible to TSH acting through the FSH receptor, Ryan et al. (27) sequenced the human FSH receptor gene in eight patients with gonadal hyperstimulation secondary to primary hypothyroidism. They found no mutations and no variance in the sensitivities of different allelic combinations or polymorphisms of the human FSH receptor. They confirmed previous study results that a very high concentration of TSH can directly cause activation of the wild-type FSH receptor (29). One may speculate that TSH could also be acting through its own receptor on the ovary, but this is considered less likely as hypothyroidism more commonly presents with ovarian insufficiency and delayed puberty (17).

The role of prolactin has long been argued in this syndrome, especially as prolactin has not been elevated in every reported case (12). Loss of negative feedback from thyroid hormones in primary hypothyroidism not only results in high TRH levels, hyperplasia of the TSHsecreting cells in the pituitary but also stimulates prolactin secretion $(5,6,13,14,30,31,32)$. In addition, elevated oestrogen concentrations reduce prolactin inhibitory factor via a negative feedback mechanism, causing a further increase in prolactin $(8,33)$. Prolactin is known to suppress pituitary gonadotropins by slowing GnRH pulse frequency $(34,35,36)$. Slow GnRH pulses preferentially lead to suppression of LH and production of FSH (37). This differential regulation may explain the discordance between FSH and LH in this syndrome. Potentially, this discrepancy could also be caused by abnormalities in the activin-inhibin-follistatin axis but these hormones were not measured (37). Cross-reactivity of such excessive TSH with FSH in standard assays is very unlikely but cannot be completely excluded, given the structural similarities between FSH and TSH, which warrants further studies.

Prolactin also sensitises the ovary to circulating gonadotropins and accelerates follicular maturation via a poorly understood mechanism $(30,38)$. Bromocriptine given to rats with hCG-induced sexual precocity inhibits ovarian cyst formation (30). However, ovarian hyperstimulation is not a recognised feature of prolactinomas, and girls with unrecognised Van Wyk-Grumbach syndrome continued vaginal bleeding despite treatment with bromocriptine (5). One would assume, however, that the pathogenesis of galactorrhoea in affected individuals is mediated by hyperprolactinaemia.

One of the unique diagnostic features of the Van Wyk-Grumbach syndrome is the combination of delayed bone age with apparent sexual precocity. Hypothyroidism leads to arrested growth and bone age delay that appears to outweigh the effect of the sexual precocity and raised circulating oestrogen. Providing thyroid hormone is adequately replaced, and there is enough time for catch up growth before true puberty occurs, it is conceivable that patients can achieve a final height within normal limits $(5,7,15,25)$.

This case presented with some unusual features, namely PTH suppression, streaky newly developed hyperpigmentation and severe anaemia. Lack of TSH causes bone loss (23). TSH in lab studies suppresses bone remodelling (39). There is poor understanding of what TSH excess, and long-standing hypothyroidism, does to bone metabolism. In our patient, TSH appeared to exert PTH-like effects with low phosphate and compensatory raised calcitonin levels whilst her PTH was suppressed, opposite to what would be expected given her vitamin D deficiency. We speculate that this PTH-like effect is exerted via TSH's own GPCR found on osteoblast and osteoclast precursors and less likely via the PTH GPCR because of profound structural difference between TSH and PTH. The fact that PTH increased during $\mathrm{T}_{4}$ replacement despite successful ergocalciferol treatment supports our hypothesis.

The association between localised skin hyperpigmentation and this syndrome was recognised by Van Wyk and Grumbach in one of the cases in their original publication (1) but there has been no mention in the literature since 
then. The speculated mechanism of development was further hormonal overlapping with the melanocytestimulating hormone (MSH) (1). MSH also acts via its GPCR and one could speculate that low-level cutaneous mosaicism of receptor distribution and activity could cause such a streaky hyperpigmentation in cases of TSH excess if homologies or cross-reactivity exist between TSH and MSH, analogous to paraneoplastic phenomena. An alternative hypothesis could be that TSH is stimulating its own epidermal TSH receptor. The presence of a streaky skin hyperpigmentation would obviously suggest a differential diagnosis of McCune Albright syndrome. Although the combination of McCune Albright syndrome and autoimmune thyroiditis may in theory result in a similar clinical picture, this diagnosis can be excluded as the skin lesion was not congenital, there was no evidence of polyostotic fibrodysplasia, bone age was delayed rather than advanced, and all hormone abnormalities vanished with $\mathrm{T}_{4}$ treatment.

Anaemia is not so uncommon in hypothyroidism (40, 41 ) and has been noted in several case reports of the Van Wyk-Grumbach syndrome $(4,6,8,9,10,18)$. The proposed mechanism involves decreased red cell production in response to the reduced metabolic requirements for oxygen in tissues in hypothyroidism $(40,41)$. In addition, the anaemia may also be exaggerated by menorrhagia, dietary deficiency or pernicious anaemia as part of an autoimmune 'cluster' (41).

In conclusion, the pathophysiology of Van WykGrumbach syndrome involves a complex mechanism, which is, at least in part, mediated by the direct action of TSH on FSH receptors. We hypothesise that the 'overlap' of hormone actions, as described by Van Wyk and Grumbach, may be exerted on a receptor level, specifically since all hormones involved use GPCRs with common intracellular signalling pathways, with the raised TSH being the suspected common culprit. Early recognition and initiation of thyroid hormone replacement can avoid further diagnostic procedure, fear of malignancy and unnecessary surgery, resolve symptoms and improve final height achieved.

\section{Declaration of interest}

The authors declare that there is no conflict of interest that could be perceived as prejudicing the impartiality of the research reported.

\section{Funding}

This research did not receive any specific grant from any funding agency in the public, commercial or not-for-profit sector.

\section{References}

1 Van Wyk JJ \& Grumbach MM. Syndrome of precocious menstruation and galactorrhoea in juvenile hypothyroidism: an example of hormonal overlap in pituitary feedback. Journal of Pediatrics 196057 416-435. (doi:10.1016/S00223476(60)80250-8)
2 Bassam T \& Ajlouni K. A case of ovarian enlargement in severe primary hypothyroidism and review of the literature. Annals of Saudi Medicine 2006 26. Downloaded from http://www.saudi annals.net on June 8 2010, IP 194.176.105.45.

3 Hansen KA, Tho SP, Hanly M, Moretuzzo RW \& McDonough PG. Massive ovarian enlargement in primary hypothyroidism. Fertility and Sterility 199767 169-171. (doi:10.1016/S0015-0282(97) 81876-6)

4 Browne LP, Boswell HB, Crotty EJ, O'Hara SM, Birkemeier KL \& Guillerman RP. Van Wyk and Grumbach syndrome revisited: imaging and clinical findings in pre- and postpubertal girls. Paediatric Radiology 200838 538-542. (doi:10.1007/s00247008-0777-1)

5 Sanjeevaiah AR, Sanjay S, Deepak T, Sharada A \& Srikanta SS. Precocious puberty and large multicystic ovaries in young girls with primary hypothyroidism. Official Journal of Endocrine Practice 200713 652-655.

6 Panico A, Lupoli GA, Fonderico F, Colarusso S, Marciello F, Poggiano MR, Del Prete M, Magliulo R, Iervolino P \& Lupoli G. Multiple ovarian cysts in a young girl with severe hypothyroidism. Thyroid 200717 1289-1293. (doi:10.1089/thy.2007.0056)

7 Niedziela M \& Korman E. Severe hypothyroidism due to autoimmune atrophic thyroiditis - predicted target height and a plausible mechanism for sexual precocity. Journal of Pediatric Endocrinology and Metabolism 200114 901-907. (doi:10.1515/ JPEM.2001.14.7.901)

8 Hunold A, Alzen G, Wudy SA, Bluetters-Sawatzki R, Landmann E, Reiter A \& Wagner HJ. Ovarian tumour in a 12-year old female with severe hypothyroidism: a case of Van Wyk and Grumbach syndrome. Pediatric Blood and Cancer 200952 677-679. (doi:10. $1002 / \mathrm{pbc} .21920)$

9 Indumathi CK, Bantwal G \& Patil M. Primary hypothyroidism with precocious puberty and bilateral cystic ovaries. Indian Journal of Pediatrics 2007 74 781-783. (doi:10.1007/s12098-007-0140-9)

10 Ozgen T, Guven A \& Aydin M. Precocious puberty in a girl with Down syndrome due to primary hypothyroidism. Turkish Journal of Paediatrics 200951 381-383.

11 Chattopadhyay A, Kumar V \& Marulaiah M. Polycystic ovaries, precocious puberty and acquired hypothyroidism: the Van Wyk and Grumbach syndrome. Journal of Pediatric Surgery $2003 \mathbf{3 8}$ 1390-1392. (doi:10.1016/S0022-3468(03)00403-2)

12 Sharma Y, Bajpai A, Mittal S, Kabra M \& Menon PSN. Ovarian cysts in young girls with hypothyroidism: follow up and effect of treatment. Journal of Pediatric Endocrinology and Metabolism 2006 19 895-900. (doi:10.1515/JPEM.2006.19.7.895)

13 Takeuchi K, Deguchi M, Takeshima Y \& Maruo T. A case of multiple ovarian cysts in a pre-pubertal girl with severe hypothyroidism due to autoimmune thyroiditis. International Journal of Gynaecological Cancer 200414 543-545. (doi:10. 1111/j.1048-891x.2004.14318.x)

14 Campaner AB, Scapinelli A, Machado RO, Dos Santos RE, Beznos GW \& Aoki T. Primary hypothyroidism presenting as an ovarian tumour and precocious puberty in a prepubertal girl. Gynaecological Endocrinology 200622 395-398. (doi:10.1080/ 09513590600819032)

15 Kamboj MK \& Musham CK. Case presentation of hypothyroidism with extreme short stature and early puberty. International Journal of Disability and Human Development 20098 317-320. (doi:10.1515/IJDHD.2009.8.3.317)

16 Singh BM, Ammini AC \& Kriplani A. Ovarian cyst in juvenile hypothyroidism. Archives of Gynaecology and Obstetrics 2005271 262-263. (doi:10.1007/s00404-003-0581-y)

17 Durbin KL, Diaz-Montes T \& Loveless MB. Van Wyk and Grumbach syndrome: an unusual case and review of the literature. Journal of Pediatric and Adolescent Gynaecology 201124 e93-e96. (doi:10. 1016/j.jpag.2010.08.003)

18 Shu J, Xing L, Zhang L, Fang S \& Huang H. Ignored adult primary hypothyroidism presenting chiefly with persistent ovarian cysts: a need for increased awareness. Reproductive Biology and Endocrinology 20119 119. (doi:10.1186/1477-7827-9-119) 
19 Sultan A, Velaga MR, Fleet M \& Cheetham T. Cullen's sign and massive ovarian enlargement secondary to primary hypothyroidism in a patient with a normal FSH receptor. Archives of Diseases in Children 200691 509-510. (doi:10.1136/adc.2005.088443)

20 Wormbecker A \& Clarson C. Acquired primary hypothyroidism: vaginal bleeding in a quiet child. Canadian Medical Association Journal 2010182 588-590. (doi:10.1503/cmaj.090883)

21 Bhansali A, Jayaprakash P, Dutta P, Walia R \& Ravikumar P. Precocious puberty and a sellar mass. BMJ Case Reports, 2009 bcr03.2009.1677.

22 Kubota K, Itho M, Kishi H, Igarashi S \& Minegishi T. Primary hypothyroidism presenting as multiple ovarian cysts in an adult woman: a case report. Gynaecological Endocrinology $2008 \mathbf{2 4}$ 586-589. (doi:10.1080/09513590802288192)

23 Kroeze WK, Sheffler DJ \& Roth BL. G-protein-coupled receptors at a glance. Journal of Cell Science 2003116 4867-4869. (doi:10. $1242 /$ jcs.00902)

24 Anasti JN, Flack MR, Froehlich J, Nelson LM \& Nisula BC. A potential novel mechanism for precocious puberty in juvenile hypothyroidism. Journal of Clinical Endocrinology and Metabolism 199580 276-279. (doi:10.1210/jc.80.1.276)

25 Bruder JM, Samuels MH, Bremner WJ, Ridgway EC \& Wierman ME. Hypothyroid-induced macroorchidism: use of a gonadotropinreleasing hormone agonist to understand its mechanism and augment adult stature. Journal of Clinical Endocrinology and Metabolism 199580 11-16. (doi:10.1210/jc.80.1.11)

26 Wagner MS, Wajner SM \& Maia AL. The role of thyroid hormones in testicular development and function. Journal of Endocrinology 2008199 351-365. (doi:10.1677/JOE-08-0218)

27 Ryan GL, Feng X, d'Alva CB, Zhang M, Van Voorhis BJ, Pinto EM, Kubias AE, Antonini SR, Latronico AC \& Segaloff DL. Evaluating the roles of follicle-stimulating hormone receptor polymorphisms in gonadal hyperstimulation associated with severe juvenile primary hypothyroidism. Journal of Clinical Endocrinology and Metabolism 200792 2312-2317. (doi:10.1210/jc.2006-2086)

28 Nakamoto JM, Franklin SL \& Geffner ME. Puberty. In Pediatric Practice: Endocrinology, 1st edn, ch 7, pp 259-298. Eds MS Kappy, DB Allen \& ME Geffner. New York: McGraw-Hill Companies, 2010.

29 De Leener A, Montanelli L, Van Durme J, Chae H, Smits G, Vassart G \& Costagliola S. Presence and absence of follicle stimulating hormone receptor mutations provide some insights into spontaneous ovarian hyperstimulation syndrome pathophysiology. Journal of Clinical Endocrinology and Metabolism 200691 555-562. (doi:10.1210/jc.2005-1580)

30 Copmann TL \& Adams WC. Relationship of polycystic ovary induction to prolactin secretion: prevention of cyst formation by bromocriptine in the rat. Endocrinology 1981108 1095-1097. (doi:10.1210/endo-108-3-1095)
31 Rosenfield RL, Cooke DW \& Radovick S. Puberty and its disorders in the female. In Pediatric Endocrinology, 3rd edn, ch 14, pp 530-609. Ed. MA Sperling. Philadelphia Saunders, Elsevier, 2008.

32 Koller K, Renee W \& Marjorie W. Thyroid hormones regulate the level of thyrotropin-releasing hormone mRNA in the paraventricular nucleus. PNAS 198784 7329-7334. (doi:10.1073/pnas.84. 20.7329)

33 Costin G, Kershnar AK, Kogut MD \& Turkington RW. Prolactin activity in juvenile hypothyroidism and precocious puberty. Pediatrics 197256 881-889.

34 Denef C. Paracrinicity: the story of 30 years of cellular pituitary crosstalk. Journal of Neuroendocrinology 200820 1-70. (doi:10. $1111 /$ j.1365-2826.2008.01676.x)

35 Krassas GE, Poppe K \& Glinoer D. Thyroid function and human reproductive health. Endocrine Reviews $2010 \quad 31 \quad 702-755$. (doi:10.1210/er.2009-0041)

36 Grattan DR, Jasoni CL, Liu XL, Anderson GM \& Herbison AE. Prolactin regulation of gonadotropin-releasing hormone neurons to suppress luteinizing hormone secretion in mice. Endocrinology 2007148 4344-4351. (doi:10.1210/en.2007-0403)

37 Thackray VG, Mellon PL \& Coss D. Hormones in synergy: regulation of the pituitary gonadotropin genes. Molecular and Cellular Endocrinology $2010 \mathbf{3 1 4}$ 192-203. (doi:10.1016/j.mce. 2009.09.003)

38 Advis JP, Richards JS \& Ojeda SR. Hyperprolactinaemia-induced precocious puberty: studies on the mechanism(s) by which prolactin enhances progesterone responsiveness to gonadotropins in prepubertal rats. Endocrinology 1981108 1333-1342. (doi:10. 1210/endo-108-4-1333)

39 Zaidi M, Davies TF, Zallone A, Blair HC, Iqbal J. Moonga SS, Mechanik J \& Sun L. Thyroid-stimulating hormone, thyroid hormones and bone loss. Current Osteoporosis Reports 20097 47-52. (doi:10.1007/s11914-009-0009-0)

40 Chu JY, Monteleone JA, Peden VH, Graviss ER \& Vernava BS. Anaemia in children and adolescents with hypothyroidism. Clinical Paediatrics $1981 \quad 20$ 696-699. (doi:10.1177/ 000992288102001102 )

41 Munro DS \& Kennedy RL. Goitre and hypothyroidism. In Clinical Endocrinology, 1st edn, ch 24, pp 293-308. Ed. A Grossman. Oxford: Blackwell Scientific Publications, 1992.

Received 5 June 2011

Revised version received 28 November 2011

Accepted 13 December 2011 